\title{
Analisis Materi Sistem Periodik Unsur Pada Buku Teks Kimia SMA/MA Kelas X
}

\author{
Anipah*, Abdul Hadjranul Fatah, Syarpin \\ Program Studi Pendidikan Kimia, Jurusan Pendidikan MIPA, FKIP, Universitas \\ Palangka Raya, Indonesia \\ E-mail: Anifahhabibah@gmail.com
}

Diterima: 06 Maret 2020; Disetujui: 21 Maret 2020; Diterbitkan: 30 Maret 2020

\begin{abstract}
ABSTRAK
Penelitian ini merupakan jenis penelitian deskriptif dengan pendekatan penelitian kualitatif. Objek penelitian ini adalah (1) Buku teks kimia SMA kelas X, penulis Unggul Sudarmo terbitan Erlangga tahun 2013 (2) Buku teks kimia SMA kelas X penulis Endang-Tarti Harjani terbitan PT. Wangsa Jatra Lestari tahun 2016. Penelitian ini dilakukan dengan menganalisis materi sistem periodik unsur pada masing-masing buku, menganalisis kesesuaian label konsep buku A terhadap buku B, analisis struktur makro wacana pada buku A dan B, analisis representasi kimia dan menganalisis label konsep buku A dab B terhadap Kurikulum 2013. Hasil menunjukkan bahwa Buku A dan B memiliki kesesuaian konsep yang cukup bagus terhadap Kurikulum 2013 dan hanya materi isotop, isoton, dan isobar yang tidak disajikan. Topik pada buku A yaitu Sistem Periodik Unsur, sedangkan pada buku B tabel periodik unsur. Pada buku A dan B samasama banyak memiliki kriteria representasi simbolik.
\end{abstract}

Kata Kunci: analisis, buku teks, representasi kimia, sistem periodik unsur

\section{PENDAHULUAN}

Kimia sebagai salah satu bidang ilmu pengetahuan alam yang terbentuk dari fakta, konsep, prinsip, teori, dan hukum, yang termasuk bagian dari pengetahuan deklaratif dan cara bagaimana pengetahuan itu terbentuk dikelompokkan dalam pengetahuan prosedural (Arifin, 2007).

Kimia merupakan subjek yang penting dalam sains, karena berhubungan banyak dengan cabang sains lainnya, serta memiliki hubungan yang luas dan berpengaruh dalam kehidupan sehari-hari (Olaleye, 2012). Ilmu kimia mempelajari tentang struktur, susunan, sifat, dan perubahan materi serta energi yang menyertai perubahan tersebut. Ilmu kimia memiliki beberapa karakteristik diantaranya: (1) bersifat abstrak, (2) konsep kimia pada umumnya merupakan penyederhanaan, (3) konsep dalam kimia bersifat berkembang dengan cepat (Kean dan Middlecamp, 1985).

Salah satu materi kimia di SMA yaitu sistem periodik unsur. Karakteristik konsep sistem periodik unsur yaitu banyak menggunakan simbol-simbol kimia yang dikaitkan dengan kehidupan sehari-hari. Materi sistem periodik unsur termasuk ke dalam jenis konsep abstrak dengan contoh yang konkret.

Hasil penelitian (Nastiti, 2012) menyatakan bahwa dalam memahami materi sistem periodik unsur sebanyak 63,33\% siswa disuatu sekolah menyatakan menemukan beberapa kesulitan. Kesulitan yang didapat oleh peserta didik adalah 
tidak terdapat gambar-gambar (fenomena submikroskopik) pada bahan ajar yang digunakan dan hanya berupa tulisan-tulisan keterangan saja.

Faktor utama yang terlibat dalam menyampaikan konsep secara langsung adalah guru. Menurut Treagust (2009) guru biasanya menganggap siswa dapat memahami konsep setiap level representasi seecara bersamaan. Bahan ajar umum yang digunakan oleh guru dalam proses pembelajaran adalah buku teks. Buku teks merupakan salah satu sumber bacaan yang berfungsi sebagai sumber bahan ajar dalam bentuk materi cetak (Prastowo, 2013). Selain itu menurut Irez (2009), buku teks merupakan salah satu sumber utama siswa untuk memperoleh pengetahuan. Jika dihubungkan dengan karakteristik pembelajaran kimia, maka buku teks yang digunakan dalam proses pembelajaran harus memuat tiga level representasi (makroskopik, submikroskopik, dan simbolik) yang saling terhubung. Menurut Irez (2009) bahwa penyajian ide yang berbeda dalam buku teks dapat mempengaruhi proses pembelajaran siswa baik secara langsung maupun tidak langsung. Oleh karena itu, diperlukan analisis terlebih dahulu terhadap buku teks pelajaran, termasuk pelajaran kimia.

Penelitian ini bertujuan untuk melakukan analisis label konsep dan representasi kimia materi sistem periodik unsur pada buku teks kimia SMA/MA kelas X. Penelitian serupa telah dilakukan Wulandari (2019).

\section{METODOLOGI PENELITIAN}

Penelitian yang dilakukan menggunakan dua buku teks kimia SMA kelas X $\mathrm{K}-13$. Kedua buku tersebut adalah buku teks kimia untuk SMA/MA kelas $X$ karangan Unggul Sudarmo yang diterbitkan oleh PT. Erlangga (buku A) dan buku teks kimia SMA/Ma kelas X karangan Endang Susilowati dan Tarti Harjani penerbit PT. Wangsa Jatra Lestrai (buku B). Pada kedua buku tersebut masingmasing dicari label konsep, struktur makro wacana, dan representasi kimia pada materi sistem periodik unsur. Penelitian ini dilaksanakan sejak bulan desember 2018 dan diselesaikan pada bulan juni 2019.

Data yang sudah dikumpulkan dari buku A dan B kemudian dianalisis sesuai instrumen yang telah dibuat. Langkah-langkah untuk analisis data yaitu:

1. Label konsep pada buku A dan buku B dimasukkan ke dalam instrumen analisis konsep kemudian diidentifikasi tipologinya sesuai dengan tipologi yang ada dengan cara diberi tanda checklist.

2. Struktur makro wacana yang terdapat pada buku A dan buku B yang sudah dikumpulkan kemudian dibuat dalam bentuk bagan sesuai dengan instrumen yang dibuat. Kemudian dianalisis dan diidentifikasi level elaborasi dan progresinya.

3. Representasi kimia yang terdapat pada buku A dan B masing-masing dimasukkan dalam label instrumen yang sudah dibuat untuk kemudian diidentifikasi berdasarkan lima kriteria Gkitzia, et al., 2011) dengan cara diberi checklist. Kemudian dianalisis berdasarkan kriteria dari masingmasing kategori yang sudah ada.

4. Materi sistem periodik unsur yang terdapat pada buku A dan buku B kemudian dibandingkan dengan materi sistem periodik unsur yang terdapat pada Kurikulum 2013, dianalisis berdasarkan data yang ada apakah sudah sesuai dengan Kurikulum 2013 yang menjadi acuan pembuatan buku-buku tersebut. 


\section{HASIL PENELITIAN DAN PEMBAHASAN}

Buku teks A adalah buku kimia untuk kelas X SMA/MA karangan Unggul Sudarmo. Konsep sistem periodik unsur dibahas pada bab 2 halaman 54. Pada penelitian ini akan dijelaskan hasil penelitian dan pembahasan mengenai hubungan label konsep dengan tipologi (makroskopik, submikroskopik, dan simbolik). Kesesuaian konsep sistem periodik unsur pada buku teks A dengan tipologi disajiikan pada tabel 7 berikut.

Tabel 7. Cuplikan fragmen hasil analisis label konsep dan jenis representasi buku $A$

\begin{tabular}{|c|c|c|}
\hline \multirow[b]{2}{*}{ Label konsep } & \multicolumn{2}{|l|}{ Tipologi } \\
\hline & Makroskopik Submikroskopik & Simbolik \\
\hline Sistem periodik unsur & & $\sqrt{ }$ \\
\hline Teori triade dobereiner & & $\sqrt{ }$ \\
\hline Teori oktaf newlands & & $\sqrt{ }$ \\
\hline Sistem periodik Mendeleev & & $\sqrt{ }$ \\
\hline Kekurangan sistem periodik & & $\sqrt{ }$ \\
\hline Mendeleev & & \\
\hline Sistem periodik modern & & $\sqrt{ }$ \\
\hline Golongan & & $\sqrt{ }$ \\
\hline Periode & & $\sqrt{ }$ \\
\hline $\begin{array}{l}\text { Hubungan konfigurasi elektron } \\
\text { dan sistem periodik unsur }\end{array}$ & & $\sqrt{ }$ \\
\hline Unsur logam & & $\sqrt{ }$ \\
\hline Unsur nonlogam & & $\sqrt{ }$ \\
\hline Titik leleh dan titik didih dalam & & $\sqrt{ }$ \\
\hline SPU & & \\
\hline Jari-jari atom & & $\sqrt{ }$ \\
\hline $\begin{array}{l}\text { Kecenderungan jari-jari atom } \\
\text { dalam SPU }\end{array}$ & & $\sqrt{ }$ \\
\hline Energi ionisasi & & $\sqrt{ }$ \\
\hline $\begin{array}{l}\text { Kecenderungan energi ionisasi } \\
\text { dalam SPU }\end{array}$ & & $\sqrt{ }$ \\
\hline Afinitas electron & & $\sqrt{ }$ \\
\hline Kecenderungan afinitas elektron & & $\sqrt{ }$ \\
\hline Harga afinitas electron & & $\sqrt{ }$ \\
\hline Keelektronegatifan & & $\sqrt{ }$ \\
\hline Kecenderungan & & $\sqrt{ }$ \\
\hline keelektronegatifan & & \\
\hline
\end{tabular}

Pada tabel 7, subbab pertama label konsep yang dibahas pertama yaitu teori Triade Dobereiner dimana terdapat tipologi simbolik pada tabel daftar unsur Triade Dobereiner pada lampiran halaman 6. Selanjutnya label konsep teori Oktaf Newlands terdapat tipologi simbolik pada tabel daftar unsur Oktaf Newlands pada lampiran halaman 87. Label konsep berikutnya yaitu label konsep sistem periodik Mendeleev terdapat tipologi simbolik dimana pada tabel yang disusun oleh Newlands dari unsur-unsur pada lampiran hal 89. Label konsep sistem periodik modern terdapat tipologi simbolik pada tabel periodik dan perbedaan cara 
penomoran golongan lama dan baru, serta perbedaan cara penomoran golongan pada lampiran halaman 90. Label konsep kekurangan sistem periodik Mendeleev tidak terdapat tipologi. Label konsep golongan dan periode juga tidak terdapat tipologi.

Label konsep pada subbab kedua yaitu label konsep hubungan konfigurasi elektron dan sistem periodik unsur terdapat tipologi simbolik pada tabel konfigurasi elektron beberapa unsur dalam sistem periodik unsur, pembagian blok dalam SPU, tabel hubungan konfigurasi antara konfigurasi elektron dan letak unsur pada sistem periodik unsur pada lampiran halaman 99.

Label konsep pada subbab ketiga terdapat label konsep unsur logam, unsur nonlogam, titik leleh dan titik didih dalam SPU, jari-jari atom, kecenderungan jari-jari atom, energi ionisasi, kecenderungan energi ionisasi, afinitas elektron, harga afinitas elektron, keelektronegatifan dan kecenderungan keelektronegatifan. Label konsep unsur logam terdapat satu tipologi yaitu simbolik pada kedudukan logam dalam sistem periodik unsur pada lampiran halaman 102. Label konsep titik leleh dan titik didih terdapat tipologi simbolik yaitu pada tabel kecenderungan titik didih dan titik leleh unsur dalam sistem periodik unsur. Label konsep jari-jari atom terdapat tipologi simbolik yaitu dimana jari-jari atom natrium lebih besar dari jari-jari atom litium dan pada tabel jari-jari atom beberapa unsur, lampiran halaman 105. Label konsep kecenderungan jari-jari atom terdapat satu tipologi yaitu simbolik dimana pada gambar kecenderungan perubahan jarijari atom (dalam psikometer) dalam sistem periodik unsur lampiran halaman 107. Label konsep energi ionisasi terdapat tipologi simbolik pada grafik kecenderungan energi ionisasi unsur-unsur lampiran halaman 109. Label konsep sifat energi ionisasi terdapat satu tipologi yaitu pada pada tabel energi ionisasi pertama unsur-unsur golongan utama $(\mathrm{Kj} / \mathrm{mol})$ lampiran halaman 110 . Label konsep afinitas elektron terdapat satu tipologi yaitu pada afinitas elektron. Label konsep pada harga afinitas elektron terdapat satu tipologi yaitu pada tabel harga afinitas elektron beberapa unsur lampiran halaman 111. Label konsep kelektronegatifan terdapat satu tipologi yaitu pada harga kelektronegatifan unsurunsur dalam sistem periodik unsur. Label konsep kecenderungan kelektronegatifan tidak terdapat tipologi.

\section{Label Konsep dan Jenis Representasi Kimia pada Buku B}

Buku teks B adalah buku kimia untuk kelas X SMA/MA karangan Endang Susilowati-Tarti Harjani. Konsep Sistem Periodik Unusr dibahas pada bab II halaman 73. Pada penelitian ini akan dijelaskan hasil dan pembahasan mengenai hubungan label konsep dengan tipologi (makroskpik, submikroskopik, dan simbolik). Kesesuaian konsep sistem periodik unsur pada buku teks B dengan tipologi dapat disajikan SEBAGAI BERIKUT.

Tabel 8. Label Konsep dan Jenis Representasi pada buku B

\begin{tabular}{|c|c|c|c|}
\hline \multirow[b]{2}{*}{ Label konsep } & \multicolumn{3}{|c|}{ Tipologi } \\
\hline & Makroskopik & Submikroskopik & Simbolik \\
\hline $\begin{array}{l}\text { Hukum triade } \\
\text { dobereiner }\end{array}$ & & & $\sqrt{ }$ \\
\hline $\begin{array}{l}\text { Hukum oktaf johnn } \\
\text { newlands }\end{array}$ & & & $\sqrt{ }$ \\
\hline
\end{tabular}




\begin{tabular}{|c|c|c|}
\hline \multirow[b]{2}{*}{ Label konsep } & \multicolumn{2}{|l|}{ Tipologi } \\
\hline & Makroskopik $\quad$ Submikroskopik & Simbolik \\
\hline $\begin{array}{l}\text { Tabel periodik } \\
\text { mendeleev }\end{array}$ & & $\sqrt{ }$ \\
\hline $\begin{array}{l}\text { Tabel periodik } \\
\text { unsur }\end{array}$ & & $\sqrt{ }$ \\
\hline $\begin{array}{l}\text { Tabel periodik } \\
\text { modern }\end{array}$ & & $\sqrt{ }$ \\
\hline Golongan & & $\sqrt{ }$ \\
\hline Periode & & $\sqrt{ }$ \\
\hline Hubungan & & $\sqrt{ }$ \\
\hline $\begin{array}{l}\text { konfigurasi elektron } \\
\text { dengan letak unsur }\end{array}$ & & \\
\hline $\begin{array}{l}\text { Sifat keperiodikan } \\
\text { unsur }\end{array}$ & & $\sqrt{ }$ \\
\hline Jari-jari atom & & $\sqrt{ }$ \\
\hline $\begin{array}{l}\text { Kecenderungan jari- } \\
\text { jari atom }\end{array}$ & & $\sqrt{ }$ \\
\hline Afinitas elektron & & $\sqrt{ }$ \\
\hline $\begin{array}{l}\text { Kecenderungan } \\
\text { afinitas elektron }\end{array}$ & & $\sqrt{ }$ \\
\hline Energi ionisasi & & $\sqrt{ }$ \\
\hline $\begin{array}{l}\text { Kecenderungan } \\
\text { energi ionisasi }\end{array}$ & & $\sqrt{ }$ \\
\hline Keelektronegatifan & & $\sqrt{ }$ \\
\hline Harga & & $\sqrt{ }$ \\
\hline keelektronegatifan & & \\
\hline Kecenderungan & & $\sqrt{ }$ \\
\hline keeleketronegatifan & & \\
\hline
\end{tabular}

Tabel 8, label konsep yang dibahas pertama pada meliputi hukum Triade Dobereiner, dimana konsep ini terdapat tipolog simbolik yaitu pada beberapa contoh hukum Triade Dobereiner yang ada pada lampiran halaman 113.

Label konsep pada subbab kedua yaitu hukum Oktaf John Newlands terdapat tipologi simbolik pada tabel periodik unsur John Oktaf Newlands gambar lampiran halaman 114. Label konsep tabel periodik Mendeleev terdapat satu tipologi yaitu simbolik pada tabel kesamaan sifat Germanium dengan Eka-Silikon dan gambar tabel periodik bentuk pendek (Mendeleev) pada lampiran halaman 116. Label konsep tabel periodik unsur tidak terdapat tipologi.

Label konsep tabel periodik modern terdapat satu tipologi yaitu simbolik pada gambar tabel periodik modern pada lampiran halaman 119. Label konsep golongan dan periode tidak terdapat tipologi.

Label konsep pada subbab kedua yaitu label konsep hubungan konfigurasi eketron dengan letak unsur. Label konsep ini terdapat tipologi simbolik pada pembagian blok unsur dan tabel hubungan konfigurasi elektron dengan golongan unsur pada lampiran halaman 121. 
Label konsep pada subbab ketiga yaitu sifat keperiodikan unsur, jari-jari atom, kecenderungan jari-jari atom, afinitas elektron, kecenderungan afinitas elektron, energi ionisasi, keelektronegatifan, harga keeleketronegatifan dan kecenderungan keeletronegatifan. Label konsep sifat keperiodikan unsur tidak terdapat tipologi. Pada label konsep jari-jari atom terdapat satu tipologi yaitu simbolik pada pola keteraturan jari-jari atom unsur golongan utama dalam tabel periodik unsur pada lampiran halaman 124. Label konsep kecenderungan jari-jari atom terdapat satu tipologi yaitu simbolik pada hubungan antara nomor atom dan jari-jari atom lampiran halaman 126. Label konsep afinitas elektron terdapat tipologi simbolik yaitu pada tabel afinitas elektron unsur-unsur golongan pada lampiran halaman 127. Label konsep kecenderungan afinitas elektron dalam SPU tidak terdapat tipologi. Label konsep energi ionisasi terdapat satu tipologi yaitu simbolik pada hubungan energi ionisasi dengan nomor atom dan tabel energi ionisasi 10 unsur yang pertama pada lampiran halaman 130. Label konsep keelektronegatifan terdapat satu sipologi yaitu simbolik pada kelektronegatifan unsur menurut Linus Pauling. Label konsep harga keelektronegatifan terdapat satu tipologi yaitu simbolik pada persamaan besar kelektronegatifan lampiran halaman 131. Label konsep kecenderungan keelektronegatifan tidak terdapat tipologi.

\section{Kesesuaian Label Konsep Pada Masing-Masing Buku}

Penelitian ini akan dijelaskan hasil dan pembahsan mengenai hubungan kesesuaian label konsep masing-masing buku pada materi sistem periodik unsur. Kesesuaian konsep sistem periodik unsur dapat disajikan pada tabel 9.

Tabel 9. Kesesuaian Label Konsep

\begin{tabular}{|c|c|c|}
\hline Label konsep & Buku A & Buku B \\
\hline Teori Johann & $\sqrt{ }$ & $\sqrt{ }$ \\
\hline Dobereiner & & \\
\hline Teori Mendeleev & $\sqrt{ }$ & $\sqrt{ }$ \\
\hline Teori Oktaff & $\sqrt{ }$ & $\sqrt{ }$ \\
\hline Newlands & & \\
\hline Tabel periodik unsur & $\sqrt{ }$ & $\sqrt{ }$ \\
\hline $\begin{array}{l}\text { Tabel periodik } \\
\text { modern }\end{array}$ & $\sqrt{ }$ & $\sqrt{ }$ \\
\hline Periode & $\sqrt{ }$ & $\sqrt{ }$ \\
\hline Golongan & $\sqrt{ }$ & $\sqrt{ }$ \\
\hline $\begin{array}{l}\text { Sistem } \\
\text { penggolongan unsur } \\
\text { dalam tabel periodik }\end{array}$ & & $\sqrt{ }$ \\
\hline $\begin{array}{l}\text { Hubungan } \\
\text { konfigurasi eletron } \\
\text { dan sistem periodik } \\
\text { unsur }\end{array}$ & $\sqrt{ }$ & $\sqrt{ }$ \\
\hline Golongan logam & $\sqrt{ }$ & - \\
\hline Golongan nonlogam & $\sqrt{ }$ & - \\
\hline Sifat keperiodikan & $\sqrt{ }$ & $\sqrt{ }$ \\
\hline $\begin{array}{l}\text { Titik leleh dan titik } \\
\text { didih dalam SPU }\end{array}$ & $\sqrt{ }$ & $\sqrt{ }$ \\
\hline
\end{tabular}




\begin{tabular}{|c|c|c|}
\hline Label konsep & Buku A & Buku B \\
\hline Jari-jari atom & $\sqrt{ }$ & $\sqrt{1}$ \\
\hline $\begin{array}{l}\text { Kecenderungan jari- } \\
\text { jari atom }\end{array}$ & $\sqrt{ }$ & $\sqrt{ }$ \\
\hline Energi ionisasi & $\sqrt{ }$ & $\sqrt{ }$ \\
\hline $\begin{array}{l}\text { kecenderungan } \\
\text { energi ionisasi }\end{array}$ & $\sqrt{ }$ & $\sqrt{ }$ \\
\hline Afinitas electron & $\sqrt{ }$ & $\sqrt{ }$ \\
\hline $\begin{array}{l}\text { Harga afinitas } \\
\text { elektron }\end{array}$ & $\sqrt{ }$ & $\sqrt{ }$ \\
\hline $\begin{array}{l}\text { Kecenderungan } \\
\text { afinitas elektron }\end{array}$ & $\sqrt{ }$ & $\sqrt{ }$ \\
\hline Keelektronegatifan & $\sqrt{ }$ & $\sqrt{ }$ \\
\hline Harga & $\sqrt{ }$ & $\sqrt{ }$ \\
\hline keelektronegatifan & & \\
\hline $\begin{array}{l}\text { Kecenderungan } \\
\text { keelektronegatifan }\end{array}$ & $\sqrt{ }$ & $\sqrt{ }$ \\
\hline
\end{tabular}

\section{Struktur Makro Pada Buku A}

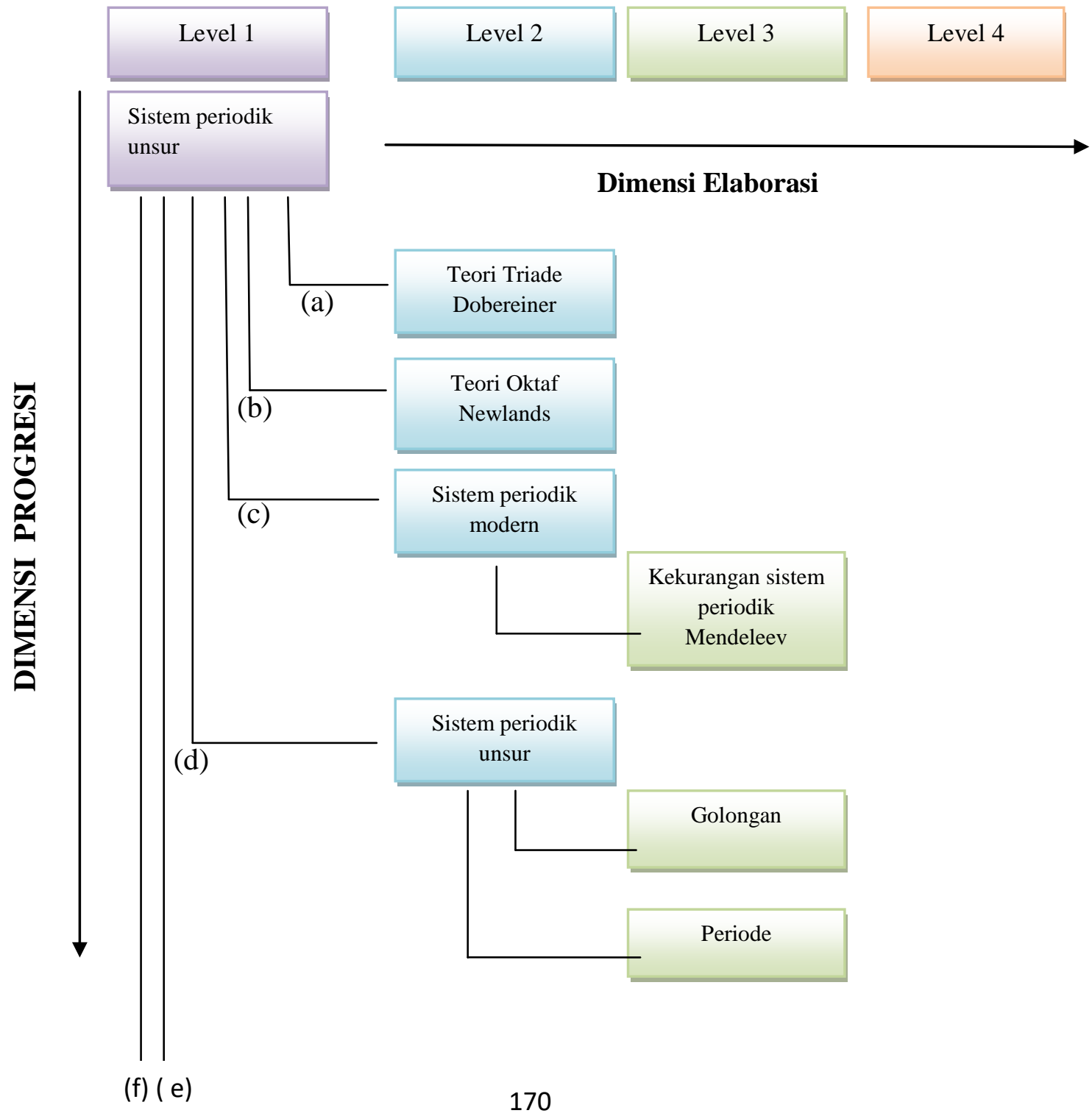


Lanjutan Struktur makro wacana buku A

(f) (e)

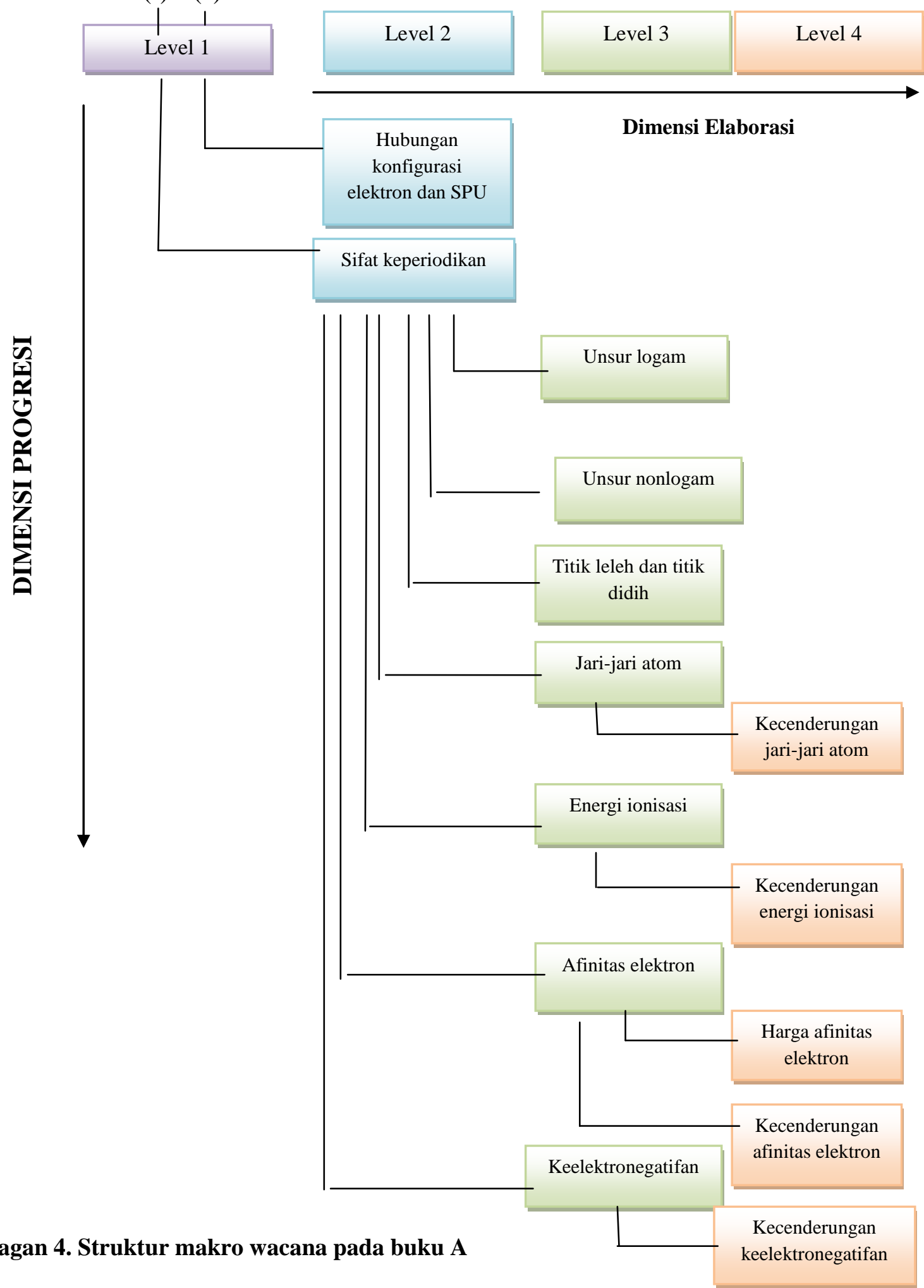




\section{Struktur Makro Pada Buku B}

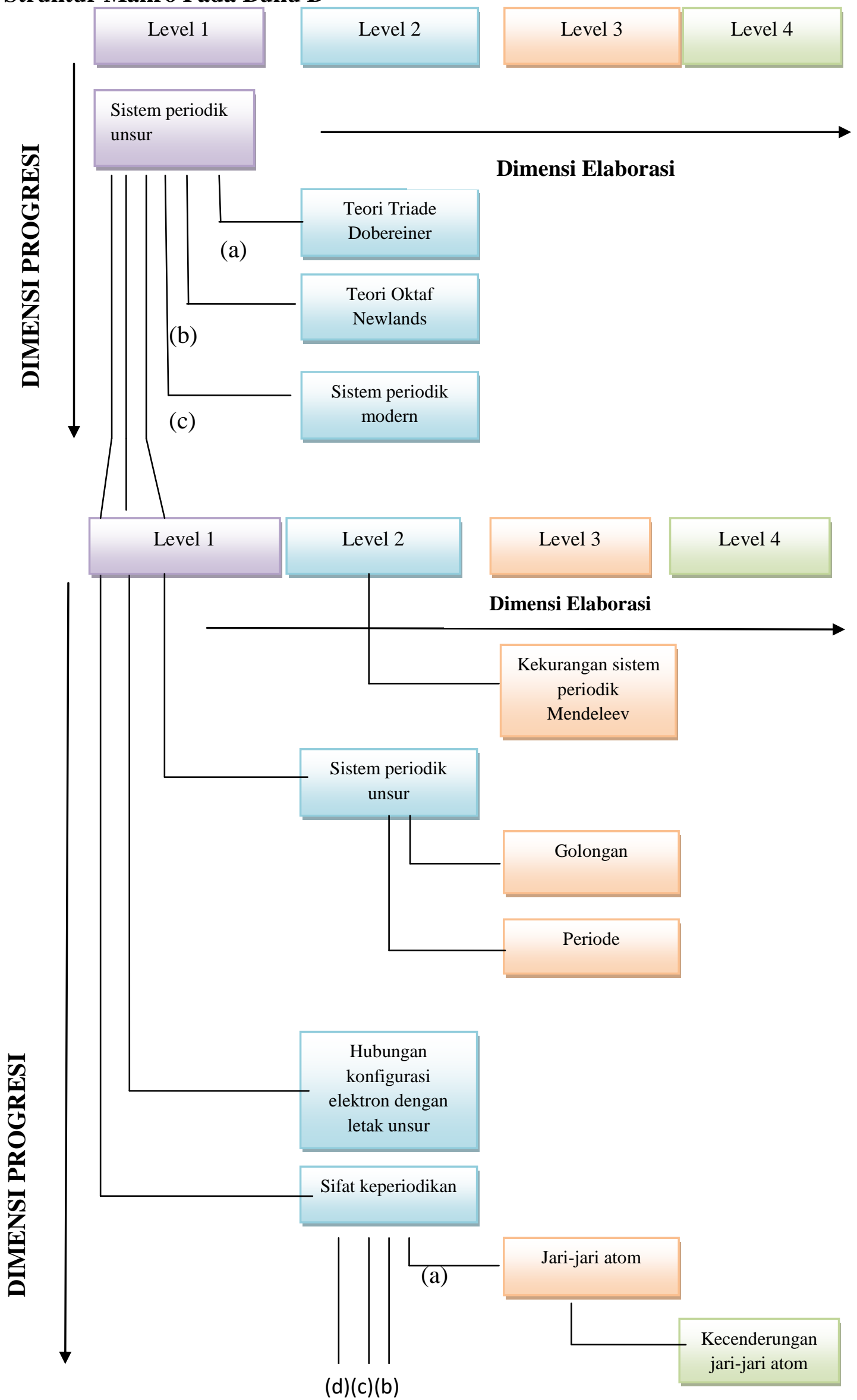




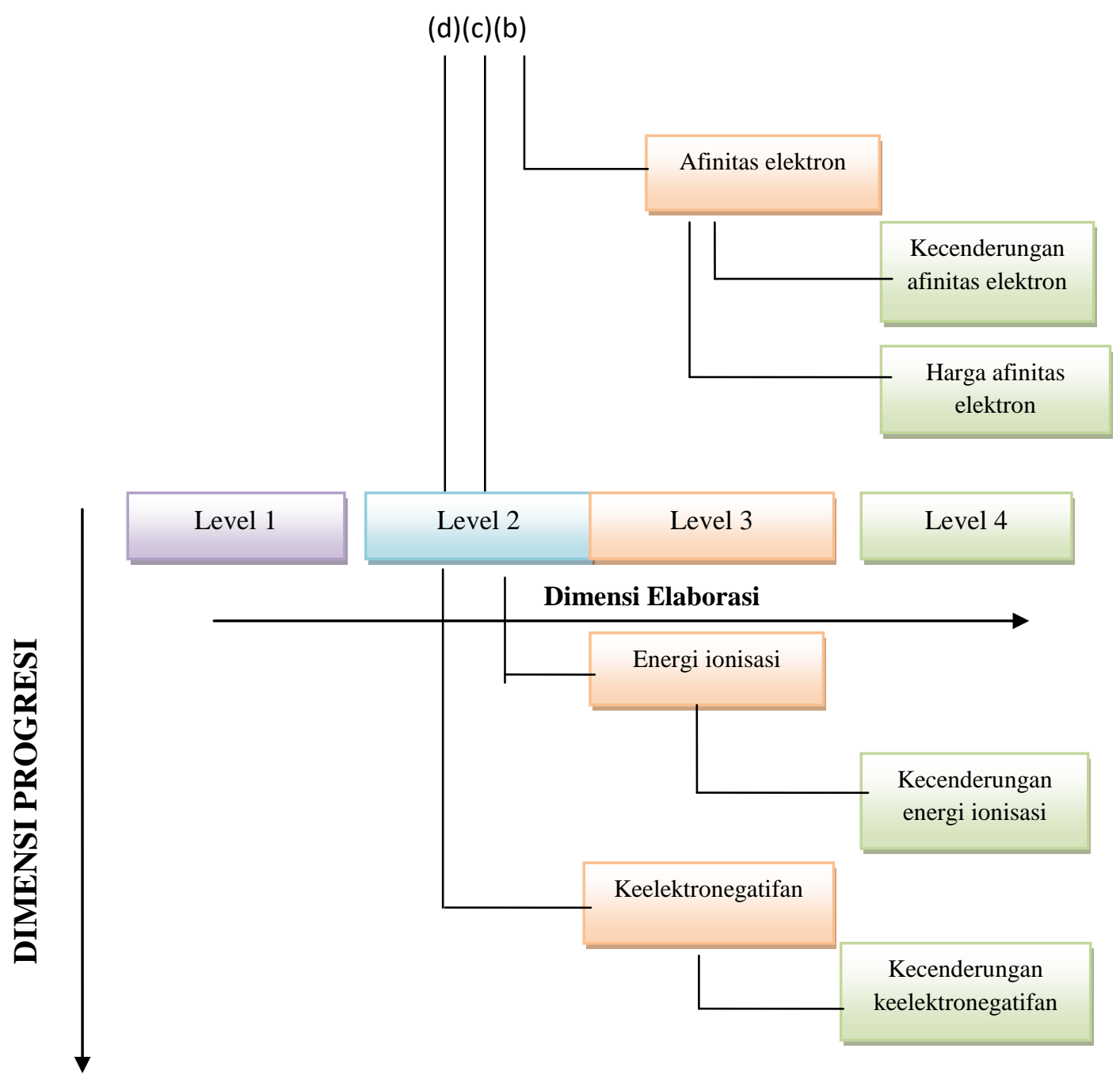

Bagan 5. Struktur makro wacana pada buku B

Analisis Representasi buku A

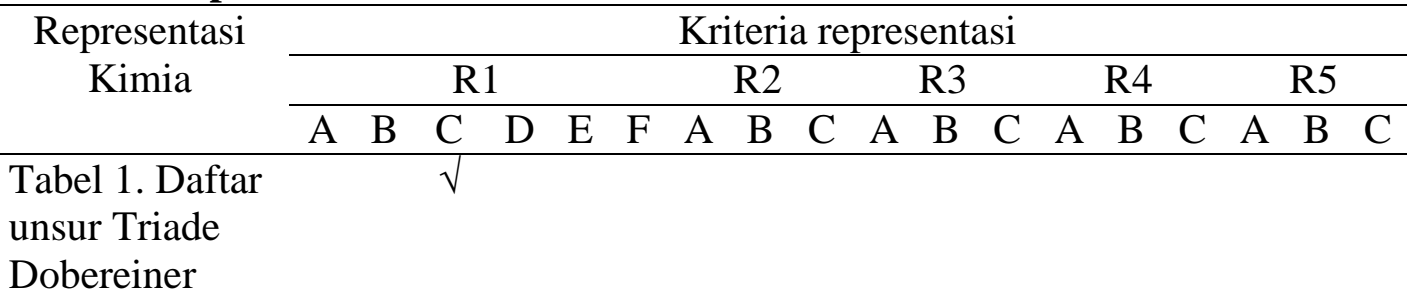

Tabel 2. Daftar unsur Oktaf

Newlands

Gambar 1.

Tabel periodik

Mendeleev

Tabel 3.

Perbandingan

sifat unsur eka

silikon dan 


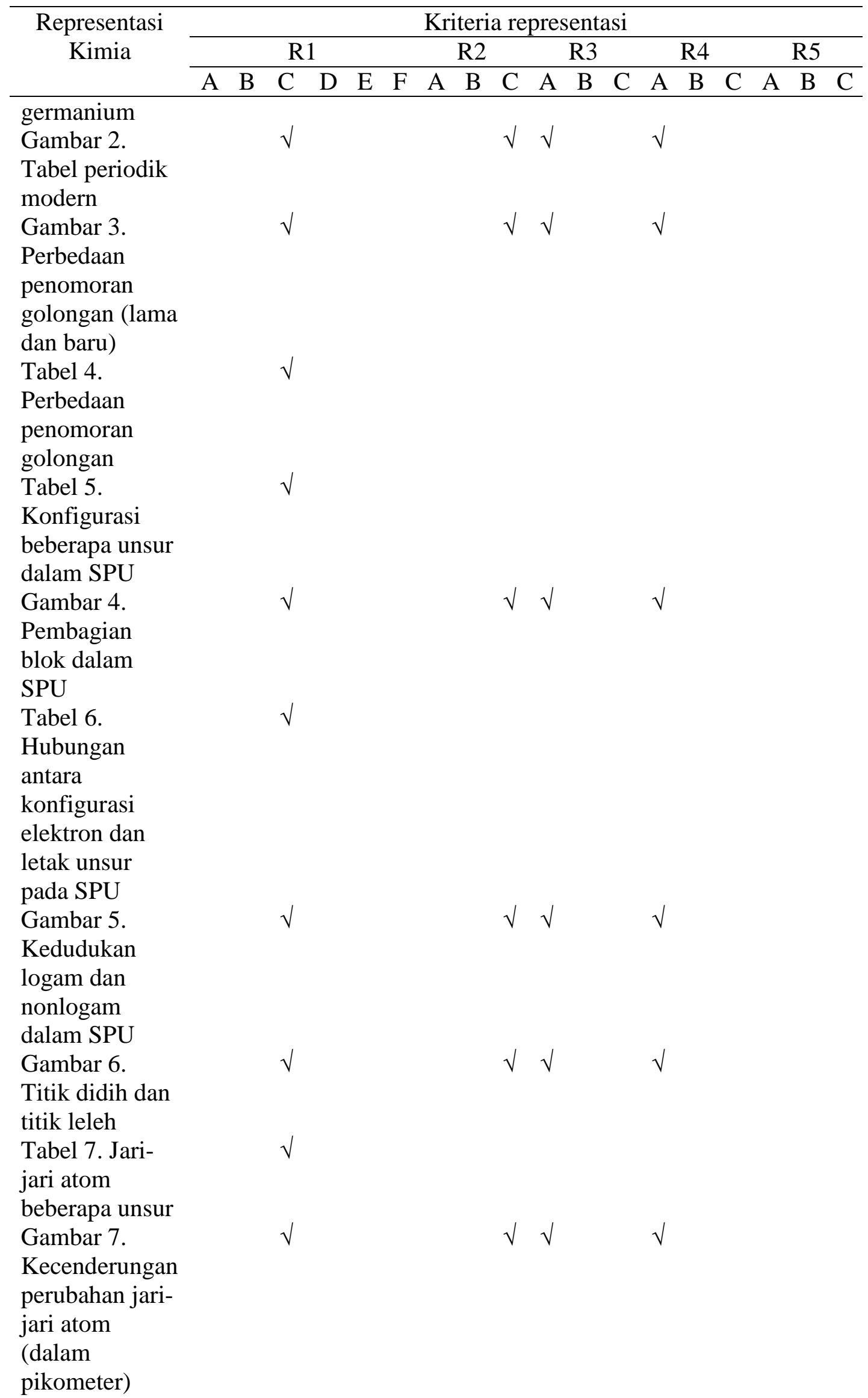




\begin{tabular}{|c|c|c|c|c|c|c|c|c|c|c|c|c|c|}
\hline \multirow{3}{*}{$\begin{array}{c}\text { Representasi } \\
\text { Kimia }\end{array}$} & \multicolumn{13}{|c|}{ Kriteria representasi } \\
\hline & \multicolumn{3}{|c|}{ R1 } & \multicolumn{2}{|c|}{ R2 } & \multicolumn{3}{|c|}{ R3 } & \multicolumn{3}{|c|}{$\mathrm{R} 4$} & \multicolumn{2}{|c|}{ R5 } \\
\hline & A B & $\mathrm{C}$ & $\mathrm{D} \quad \mathrm{E} \quad \mathrm{F}$ & A $B$ & $\mathrm{C}$ & $\mathrm{A}$ & B & $\mathrm{C}$ & A & $\mathrm{B}$ & $\mathrm{C}$ & A $B$ & $\mathrm{C}$ \\
\hline \multicolumn{14}{|l|}{ pada SPU } \\
\hline \multicolumn{14}{|l|}{ Gambar 8.} \\
\hline \multicolumn{14}{|l|}{ Energi ionisasi } \\
\hline \multicolumn{14}{|l|}{ unsur-unsur } \\
\hline \multicolumn{14}{|l|}{ golongan } \\
\hline \multicolumn{14}{|l|}{ utama } \\
\hline \multicolumn{14}{|l|}{ Tabel 8. Energi } \\
\hline \multicolumn{14}{|l|}{ ionisasi } \\
\hline \multicolumn{14}{|l|}{ pertama unsur- } \\
\hline \multicolumn{14}{|l|}{$\begin{array}{l}\text { unsur golongan } \\
\text { utama }\end{array}$} \\
\hline \multicolumn{14}{|l|}{ Tabel 9. Harga } \\
\hline \multicolumn{14}{|l|}{ afinitas } \\
\hline \multicolumn{14}{|l|}{ elektron } \\
\hline \multicolumn{14}{|l|}{ beebrapa unsur } \\
\hline \multicolumn{14}{|l|}{ Gambar 9.} \\
\hline \multicolumn{14}{|l|}{ Harga } \\
\hline \multicolumn{14}{|l|}{ keelektronegati } \\
\hline \multirow{2}{*}{\multicolumn{14}{|c|}{$\begin{array}{l}\text { fan unsur- } \\
\text { unsur dalam }\end{array}$}} \\
\hline & & & & & & & & & & & & & \\
\hline \multicolumn{14}{|l|}{ SPU } \\
\hline Jumlah & & 1 & & & 9 & 9 & & & 9 & & & & \\
\hline & & 8 & & & & & & & & & & & \\
\hline
\end{tabular}

Tabel 10. Kriteria Representasi Pada Buku Teks B

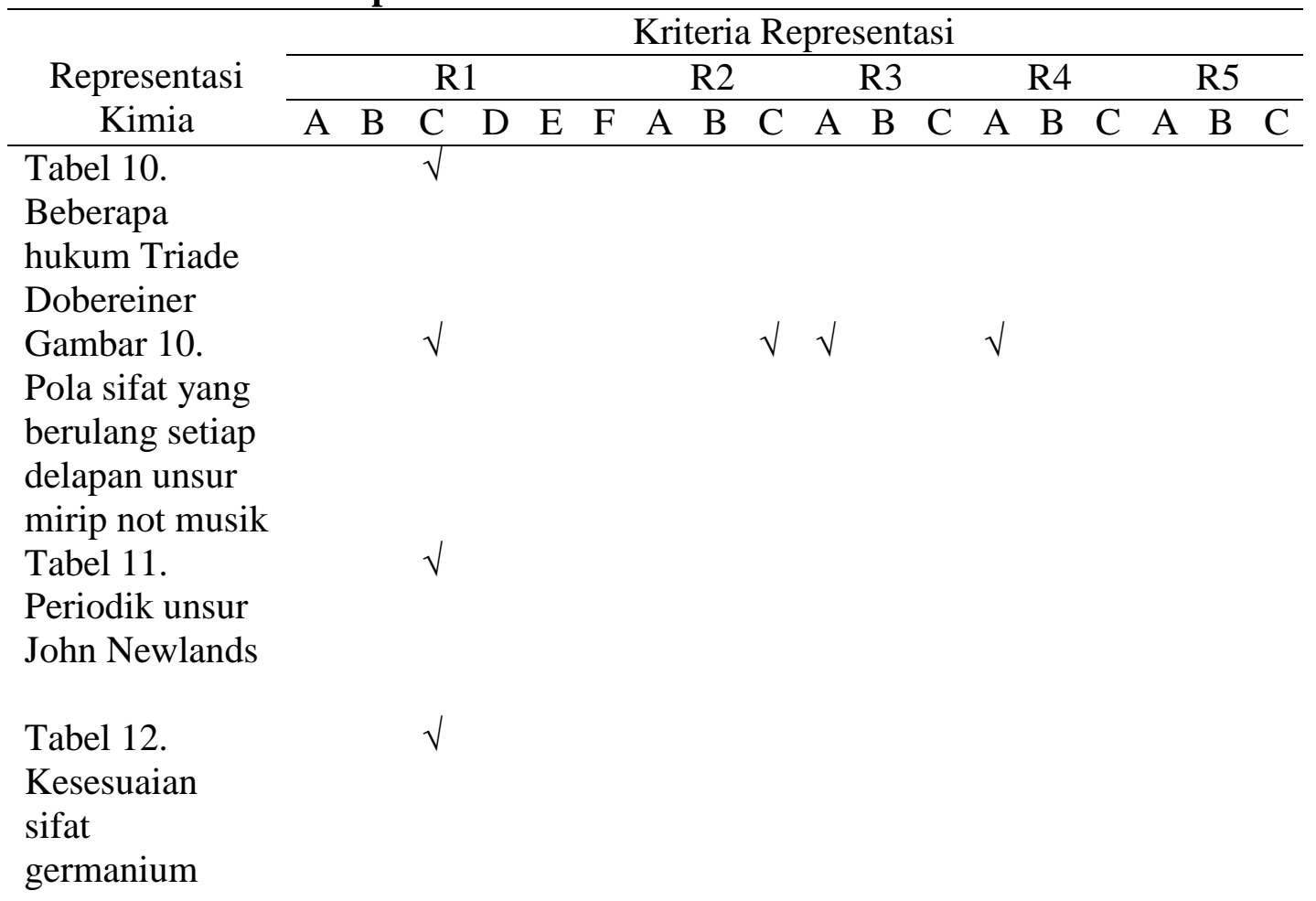




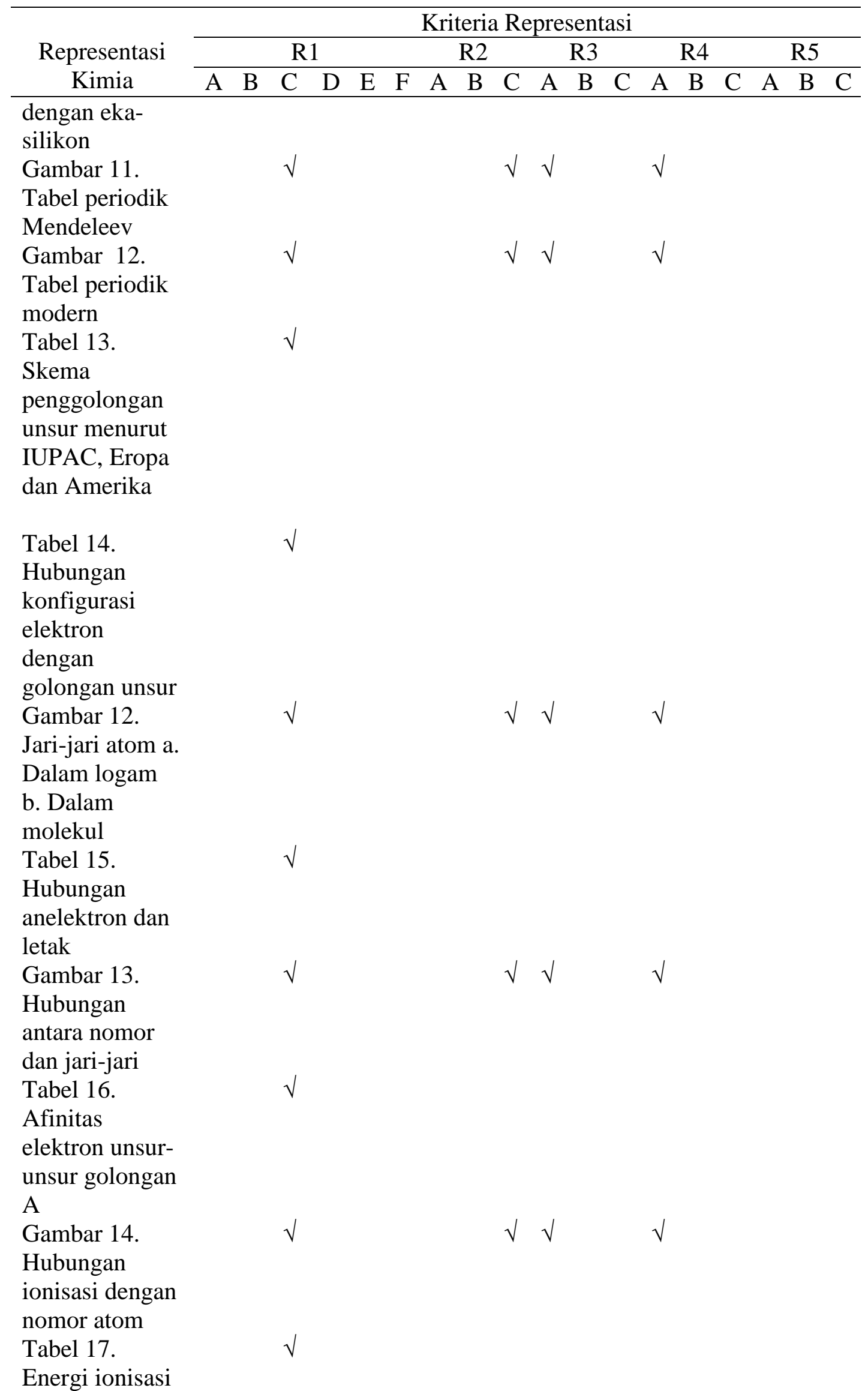




\begin{tabular}{|c|c|c|c|c|c|c|c|c|c|c|c|c|c|c|c|c|}
\hline \multirow{3}{*}{$\begin{array}{c}\text { Representasi } \\
\text { Kimia }\end{array}$} & \multicolumn{16}{|c|}{ Kriteria Representasi } \\
\hline & \multicolumn{5}{|c|}{$\mathrm{R} 1$} & \multicolumn{3}{|c|}{$\mathrm{R} 2$} & \multicolumn{3}{|c|}{ R3 } & \multicolumn{2}{|c|}{$\mathrm{R} 4$} & \multicolumn{3}{|c|}{$\overline{\mathrm{R} 5}$} \\
\hline & A $\mathrm{B}$ & $\mathrm{C}$ & $\mathrm{D}$ & $\mathrm{E}$ & $\mathrm{F}$ & A & B & $\mathrm{C}$ & A & B & $\mathrm{C}$ & A B & $\mathrm{C}$ & A & $\mathrm{B}$ & $\mathrm{C}$ \\
\hline \multicolumn{17}{|l|}{ 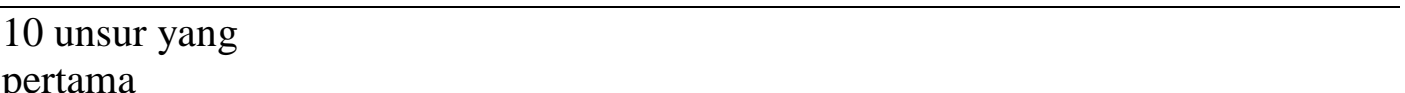 } \\
\hline \multicolumn{17}{|l|}{ Gambar 15.} \\
\hline \multicolumn{17}{|l|}{ Keelektronegati } \\
\hline \multicolumn{17}{|l|}{ fan unsur } \\
\hline \multicolumn{17}{|l|}{ menurut Linus } \\
\hline \multicolumn{17}{|l|}{ Pauling } \\
\hline \multirow[t]{2}{*}{ Jumlah } & & 1 & & & & & & 8 & 8 & & & 8 & & & & \\
\hline & & 5 & & & & & & & & & & & & & & \\
\hline
\end{tabular}

Perbandingan jumlah kriteria pada masing-masin buku ini jelas bahwa buku A dan B memiliki banyak persamaan yaitu banyak menampilkan kriteria representasi simbolik. Pada buku A jenis representasi simbolik ada 18 sedangkan pada buku B ada 15. Kemudian pada jenis surface future (R2) pada buku A ada 9 dan pada buku $\mathrm{B}$ ada 8 . Jenis representasi terkait keterhubungan keterangan dengan gambar (R2) ambigu (C) pada buku A ada 9 dan pada buku B ada 8. Dan pada jenis representasi keterngan gambar (R4) memiliki keterangan gambar yang sesuai (A) pada buku A ada 9 dan pada buku B ada 8 .

\section{SIMPULAN}

Berdasarkan analisis konsep, kedua buku teks kimia SMA sudah memenuhi konsep materi sistem periodik unsur yang ditentukan oleh K-13 yaitu golongan dan periode, sifat keperiodikan meskipun materi isotop, isobar dan isoton tidak masuk dan berada pada subbab sebelumnya. Berdasarkan analisis struktur makro wacana, kedua buku teks kimia SMA terdapat perbedaan. Topik pada buku A adalah sistem periodik unsur, sedangkan pada buku B adalah tabel periodik unsur. Berdasarkan analisis representasi, kedua buku memiliki perbedaan. Pada buku A jumlah representasi (R1) simbolik (C) 18 dan pada buku B 15. Pada jenis representasi surface future (R2) ambigu (C) pada buku A ada 9 dan buku ada 8. Jenis representasi kesesuaian dengan isi teks (R3) terkait sepenuhnya (A) pada buku A ada 9 dan buku B ada 8. Jenis representasi pada keterangan gambar (R4) memiliki keterangan gambar yang sesuai (A) pada buku A ada 9 dan B ada 8 .

\section{DAFTAR PUSTAKA}

Arifin. 2007. Strategi Belajar Mengajar Kimia. Common Textbook (Edisi Revisi). Bandung: Jurusan Pendidikan Kimia FPMIPA UPI.

Eriyanto. 2001. Analisis Wacana: Pengantar Analisis Teks Media. Yogyakarta

Gilbert, J.K. dan Treagust, D. 2009. Introduction: Macro, Submicro and Symbolic Representations and the Relationship Between Them: Key Models in Chemical Education, dalam Gilbert dan Treagust (Eds). Multiple Representations in Chemical Education, Model and Modeling in Science Education. Dorgrecht: Springer. 
Gkitzia, V., Salta, K dan Tzougraki, C. 2011. "Development and Application of Suitable Criteria for the Evaluation of Chemical Representations in School Textbooks", Chemistry Education Research and Practice.

Herron, J. D. 1977. Problems Associated With Concept Analysis. Journal of Science Education.

Johnstone, A.H. 1982. Macro and Micro Chemistry. School Science Review.

Kean, E. dan Middlecamp, C. 1985. A Survival Manual for General Chemistry (Paduan Belajar Kimia Dasar). Penerjemah: A. Hadyana Pudjaatmaka. Jakarta: Gramedia

Murry, Mc, J E. dan Fay. 2016. Chemistry Seventh Edition. New Work.

Shopariah, N. 2014. Analisis Bahan Ajar Sifat Koligatif Larutan pada Buku Teks Kimia Berdasarkan Kriteria Keterhubungan Representasi Kimia. Tasikmalaya

Sulistyowati, N. 2012. Efektivitas Model Pembelajaran Guided discovery learning Berbantuan Smart-worksheet Ditinjau Dari Hasil Belajar dan Kemampuan Pemecahan Masalah Kimia. Under Graduates thesis, Universitas Negeri Semarang.

Olayele. 2012. Enhancing Teachers" Knowledge for Using Multiple Representations in Teaching Chemistry in Nigerian Senior Secondary Schools." Australia: Edith Cowan Universit

Sudarmo, U. 2013. Kimia Untuk SMA/MA Kelas X. Jakarta: Erlangga

Sunyono. 2015. Pembelajaran Model Simayang Tipe II untuk Meningkatkan Model Mental dan Penguasaan Konsep. FKIP. Universitas Lampung

Susilowati, E. Dan Harjani, T. 2014. Kimia 1 Untuk Kelas X SMA dan MA. Solo: PT. Wangsa Jatra Lestari

Suyatinah. 2011. Analisis Buku Teks Bahasa Indonesia Sekolah Dasar Kelas II. Yogyakarta: Laporan Penelitian FIP-UNY

Tarigan, H, G. 1986. Membaca Sebagai Suatu Keterampilan Berbahasa. Bandung: Angkasa.

Tarigan, H, G. 2009. Telaah Buku Teks Bahasa Indonesia. Bandung : Penerbit Angkasa. 
Wulandari, S.H., Fatah, A.H. and Anggraeni, M.E. 2019. Analisis Materi Ajar Kimia SMA/MA Kelas XII Pada Konsep Sifat Koligatif Larutan. Jurnal Ilmiah Kanderang Tingang. 10, 2 (Des. 2019), 300-320.

Zumdahl. 2007. Chemistry Seventh Edition. New Work: Houghtn Mifflin Compani. 